\title{
Increased geographical distribution of Potamorrhaphis guianensis (Jardine, 1843) (Beloniformes: Belonidae) in the Brazilian Amazon Region
}

\section{Rafael Anaisce das Chagas ${ }^{1}$ and Mara Rúbia Ferreira Barros ${ }^{2}$ \\ ${ }^{1}$ Universidade Federal Rural da Amazônia. Laboratório de Ecologia Bentônica Tropical. Avenida Perimetral, S/№. Terra Firme. Belém-PA, Brazil (CEP 66077- 830). Email: rafaelanaisce@hotmail.com. \\ ${ }^{2}$ Universidade Federal Rural da Amazônia. Programa de Pós-Graduação em Aquicultura e Recursos Aquáticos Tropicais. Estrada Principal da UFRA, 2501. Montese. Belém-PA, Brazil (CEP 66077-530).}

\begin{abstract}
This study reports the first occurrence of Potamorrhaphis guianensis (Jardine, 1843) (Beloniformes: Belonidae) in the Praquiquara Igarapé, located in the Northeast Atlantic Basin of Brazil. As the distribution of this species was delimited in the Amazon, Orinoco and Paraná Basins, it is concluded that in recent years there has been an increase in the geographic distribution of P. guianensis in the Amazon Region.
\end{abstract}

Keywords: Teleostei; Needlefishes; Biogeography; New record.
Received

December 19, 2018

Accepted

December 29, 2018

Released

December 31, 2018

Full Text Article

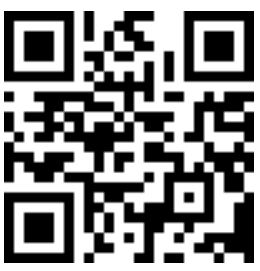

ORCID

(1) 0000-0002-1555-6154

Rafael Anaisce das

Chagas

D) $0000-0003-1354-7550$

Mara Rúbia Ferreira

Barros 
The Belonidae Family, commonly known by needlefishes, has 10 genera and 48 species of fish that are distributed in the coastal region of the American continent (East Pacific and West Atlantic) and in freshwater basins of Central and South America (Lovejoy et al., 2001; Lovejoy and Collette, 2003). In the Neotropical Region there are three genera that live exclusively in fresh water (Potamorrhaphis, Pseudotylosurus and Belonion) (Goulding and Carvalho, 1984; Collette, 2003; Lovejoy and Collette, 2003). Of these, currently the genus Potamorrhaphis presents more diverse, including four species (Sant'Anna et al., 2012). The morphological peculiarities of the genus Potamorrhaphis make their species distinguish themselves from other needlefishes (Collette, 1982). Such species are generally found in lakes and streams of the Amazon Basins, Orinoco, Paraná and coastal basins of the Guianas (Collette, 1982; Goulding and Carvalho, 1984).

In this, the first occurrence of Potamorrhaphis guianensis (Jardine, 1843) is recorded in the Praquiquara Igarapé, located in the Atlantic Northeast Atlantic Basin of Brazil.
The Praquiquara Igarapé, where P. guianensis was recorded, is located in the Castanhal Municipality, which belongs to the Brazilian Atlantic Northeast Hydrographic Region, which is constituted by the river basins that flow in the Atlantic (Northeast), being limited to the West by the Hydrographic Region of Tocantins/Araguaia, and to the East by the Hydrographic Region of Parnaíba (Pará, 2012).

The two $P$. guianensis were recorded in December 2014, being collected with a $10 \mathrm{~mm}$ mesh jar, morphometry was performed and a photograph was recorded to help identify taxonomy, based on the morphological characteristics proposed by Sant'Anna et al. (2012). After the morphometric measurement, the individuals were returned to the water body.

The two individuals of the species $P$. guianensis (Figure 1) found in the Praquiquara Igarapé had a very similar total body length (Table 1) with $25.96 \mathrm{~cm}$ and $25.70 \mathrm{~cm}$, respectively. The individuals were found in an area of the stream where the water movement is almost imperceptible.

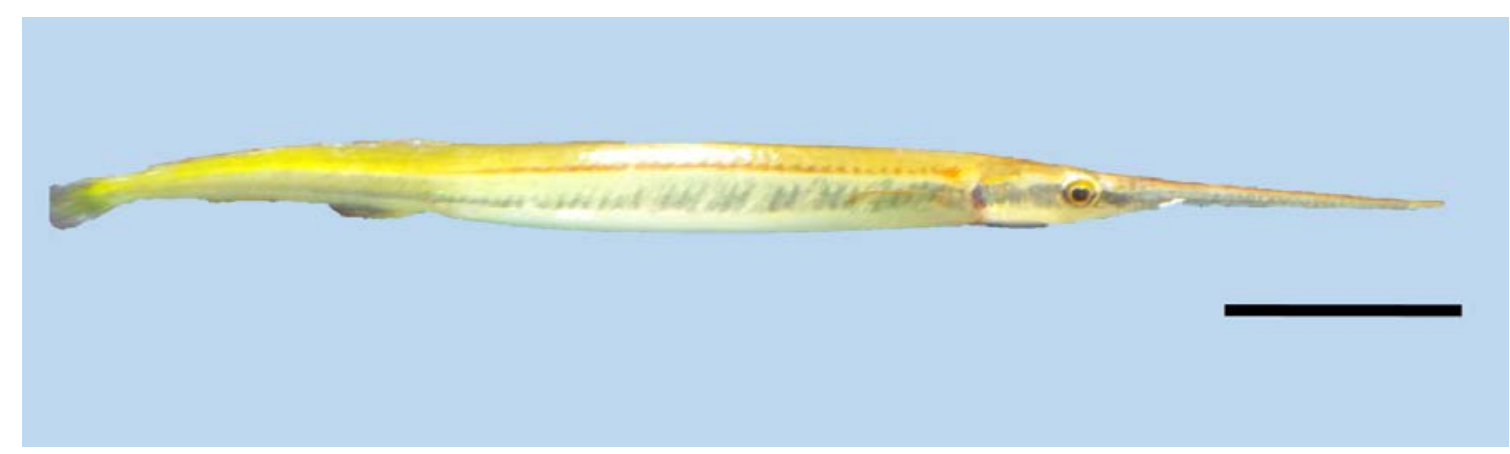

Figure 2. Potamorrhaphis guianensis (Jardine, 1843) recorded in the Praquiquara Igarapé. Scale = $5 \mathrm{~cm}$.

Although $P$. guianensis is more widely distributed in the Amazon Region, the Amazon, Orinoco and Guyana Basins were delimited (Collette, 2003; Sant'Anna et al., 2012). Since the occurrence in the Brazilian Northeast 
Atlantic Hydrographic Region, it is evident the expansion of its geographic distribution in the Brazilian territory and, consequently, in the Amazon Region. It is noteworthy that in the Praquiquara Stream recently, the occurrence of electric fish Electrophorus electricus (Linnaeus, 1766) was recorded, which also, consequently, shows the increase in its geographic distribution in the Amazon Region (Chagas et al., 2017).

Table 1. Biometric measurements $(\mathrm{cm})$ of the specimen of Potamorrhaphis guianensis collected at the Praquiquara Igarapé, in December 2014.

\begin{tabular}{lcc}
\hline Biometric parameters & Individual 1 & Individual 2 \\
\hline Total length & 25.96 & 25.70 \\
Standard length & 25.26 & 24.45 \\
Maximum body height & 1.77 & 1.42 \\
Preorbital length & 6.48 & 6.70 \\
Head height & 1.37 & 1.02 \\
Eye height & 0.60 & 0.52 \\
Eye diameter & 0.71 & 0.65 \\
Pectoral to anal distance & 9.32 & 9.47 \\
Preanal length & 11.83 & 11.44 \\
Dorsal to anal fin distance & 1.48 & 1.30 \\
Trunk length & 9.78 & 9.17 \\
Head length & 8.87 & 8.74 \\
Height of the caudal pendulum & 0.59 & 0.62 \\
Length of jaw & 5.86 & 6.19 \\
\hline
\end{tabular}

The ichthyofauna of the Amazon Region has been historically studied, however, the work mostly delimits the Amazon Basin and the Orinoco Basin. This fact makes many Amazonian species present their geographical distribution limited to these two regions. In this way, this work evidences a need for more studies aiming at the characterization of the ichthyofauna of the other hydrographic basins present in the Amazon Region.

\section{Acknowledgements}

The authors thank the Instituto Socioambiental e dos Recursos Hídricos (ISARH) and the Federal Rural University of Amazonia (UFRA) for their logistic support in the characterization project of the Praquiquara Igarapé fish community, during the years 2014 and 2015.

\section{Conflicts of interest}

Authors declare that they have no conflict of interests.

\section{References}

Chagas, R. A.; Barros, M. R. F.; Santos, W. C. R.; MHerrmann, M. Primeiro registro do peixeelétrico Electrophorus electricus (Linnaeus, 1766) (Gymnotiformes: Gymnotidae) no Igarapé Praquiquara, Castanhal, Pará. Acta of Fisheries and Aquatic Resources, v. 5, no. 1, p. vi-xi, 2017. Available from: $<$ https://seer.ufs.br/index.php/ActaFish/arti cle/view/5823>. Accessed on: Apr. 23, 2018.

Collette, B. B. South American freshwater needlefishes of the genus Potamorrhaphis (Beloniformes: Belonidae). Proceedings of the Biological Society of Washington, v. 95, p. 714-747, 1982. Available from: <https://www.biodiversitylibrary.org/part/ 48317>. Accessed on: Apr. 23, 2018. 
Collette, B. B. Family Belonidae Bonaparte 1832. Annotated Checklist of Fishes, no. 16, p.1-22, 2003. Available from: $<$ https://www.calacademy.org/sites/default /files/assets/docs/belonidae.pdf >. Accessed on: Apr. 23, 2018.

Goulding, M.; Carvalho, M. L. Ecology of Amazonian needlefishes (Belonidae). Revista Brasileira de Zoologia, v. 2, no. 3, p. 99-111, 1984. http://doi.org/10.1590/S010181751983000300002

Lovejoy, N. R.; Collette, B. B. Belonidae. In: Reis, R. E.; Kullander, S. O.; Ferraris Jr., C. J. Check list of the freshwater fishes of South and Central America. Porto Alegre: Edipucrs, 2003. p. 586-588.

Lovejoy, N. R.; Collette, B. B.; McEachran, J. D. Phylogenetic relationships of New World needlefishes (Teleostei: Belonidae) and the biogeography of transitions between marine and freshwater habitats. Copeia, v. 2001, no. 2, p. 324-338, 2001. https://doi.org/ 10.1643/0045-8511(2001)001[0324:

PRONWN]2.0.CO;2
Pará. Política de Recursos Hídricos do Estado do Pará. Belém: SEMA, 2012 Available from: <https://www2.mppa.mp. $\mathrm{br} /$ sistemas/gcsubsites/upload/41/POLITIC A_DE_RECURSOS_HIDRICOS_DO_ESTADO_DO _PARA.pdf>. Accessed on: Apr. 23, 2018.

Sant'Anna, V. B.; Delapieve, M. L. S.; Reis, R. E. A new species of Potamorrhaphis (Beloniformes: Belonidae) from the Amazon Basin. Copeia, v. 2012, no. 4, p. 663-669, 2012. https://doi.org/10.1643/CI-12-032 